\title{
Mallin kautta opitun tunnustamiseen
}

Riva Aalto, Maarit Humalajärvi, Maria Laine, Kirsti Soukka, Solveig Thun-Wilén, Ulla Tujula \& Päivi Varjosalo (2006). Taiteesta käsin. Käsityön taiteen perusopetus aikuisille. Malli visuaalisten taiteiden laajan oppimäärän opetussuunnitelman perusteiden mukaisista opinnoista. Vapaan sivistystyön yhteisjärjestö.

aiteen perusopetus on osoittautunut hyväksi väyläksi ihmisten luovan ilmaisun kehittämiseen. Lasten ja nuorten toiminnasta on saatu erinomaisia näyttöjä. Osa käsityökoulun käyneistä on päätynyt käsi- ja taideteollisuusalan ammatteihin, mutta jokainen on saanut hyviä eväitä elämään. Taiteen perusopetusta suunnataan myös aikuisille. Aikuisten käsityön taiteen perusopetus edellyttää erilaisia lähestymistapoja kuin lapsille ja nuorille suunnattu toiminta.

Taiteen perusopetuksen opettajat ovat kaivanneet lisää tietoa ja tukea työlleen. Tämä kirja on yksi vastaus tähän tarpeeseen. Kirjaan on koottu kokemuksia ja näkemyksiä aikuisille suunnatun taiteen perusopetuksen kokeiluja kehittämistyöstä eräissä kansanopistoissa ja kansalais- ja työväenopistoissa. Kokeilu- ja kehittämistyön tuloksena on luotu opintokokonaisuusmalli, joka noudattaa opetushallituksen visuaalisten taiteiden laajan oppimäärän käsityön opetussuunnitelman perusteita. Yhtenä lähtökohtana on ollut opitun tunnustaminen eri oppilaitoksissa ja työelämässä. Kirjan kirjoittajat ovat kokeilussa aktiivisesti toimineita opettajia.
Kirja on rakennettu kolmesta osasta. Ensimmäisessä osassa johdatellaan lukija aikuisten oppimiseen eräiden oppimiskäsitysten pohjalta ja esitellään opintokokonaisuusmallin lähtökohdat ja rakenne sekä tarkastellaan arviointia osana opetusta. Toisessa osassa esitellään aikuisten käsityön taiteen perusopetukselle asetetut yleiset puitteet sekä opetuksen järjestäminen kokeiluopistoissa. Kolmannessa osassa esitellään konkreettisia toteutettuja opintoja. Kuvaukset ovat kirjan kohdejoukolle todennäköisesti tärkeintä antia. Osassa kolme on esitelty kokeilussa mukana olleet opistot ja niiden toiminta käsityön taiteen perusopetuksessa.

Kirjan viimeiseen kappaleeseen on tiivistetty kirjoittajien pääviestit. Esitetty opintokokonaisuusmalli muodostuu moduuleista, jotka on mitoitettu opintopisteinä. Kirjoittajien mukaan taustalla on kokonaisvaltainen näkemys käsityön suunnitteluja valmistusprosessista, mitä sillä tarkoitetaankaan. Toivottavasti ainakin materiaalien ja tekniikoiden monialaisuutta. Opintokokonaisuusmallilla pyritään yhteismitalliseen opintojen järjestämiseen ja yhtenäistämiseen. Tämä herättää lukijassa vastustusta, kuinka voidaan yhtenäistää ja yhteismitallistaa jotain sellaista, jonka luonteeseen kuuluu uniikki ja erilaisuus? Mallin todetaan kuitenkin olevan joustava oppilaitoksen ja opiskelijan kannalta. Toivottavasti se myös sallii opettajan persoonallisen panoksen. Kysymys on vaikea, on luonnollista että tarvitaan jonkinlaista yhteismitallisuutta, mutta missä kulkee raja? Miten malli olisi lähinnä apu ja tuki ei rajoite? Siis kuinka päästäisiin siihen, että toimiva malli auttaisi täyttämään vaaditut ehdot ja mahdollistaisi keskittymisen kaikkein tärkeimpään. Kirjassa korostetaan viisaasti henkilökohtaisen opetussuunnitelman ja vuorovaikutuksen merkitystä. Toinen haastava asia on arviointi, joka ehkä liittyy luonnollisesti asioihin, joita yhteiskunta tukee taloudellisesti. On vaikea arvioida sellaista, mihin ei ole oikeaa vastausta, mutta pääpaino lieneekin opiskelijan edistymisessä. Arviointi vaatii opettajalta erityistä ymmärrystä ja oivallusta, jotta siitä muodostuisi kannustavaa ja se tukisi opiskelijaa löytämään oman ilmaisunsa.

Kaikkiaan kirja on käytännöllisen ja selkeän oloinen opas lähinnä aikuisten käsityön taiteen perusopetuksessa toimiville. Kirjallisuusluettelo on hyödyllinen ja samoin kuin liitteenä olevat lomakkeet.

Marketta Luutonen 